\title{
DETEKSI OTOMATIS KANKER PAYUDARA MENGGUNAKAN METODE MORPHOLOGICAL RECONSTRUCTION DENGAN K-MEANS CLUSTERING PADA CITRA MRI
}

\author{
Gunawan ${ }^{1}$, Robi Aziz Zuama², Ramdhan Saepulrohman³, Hamdun Sulaiman4, Muhamad Abdul \\ Ghani ${ }^{5}$ \\ 1,2,3,4,5 Universitas Bina Sarana Informatika \\ email: gunawan.gnz@bsi.ac.id, robi.rbz@bsi.ac.id,ramdhan.rpe@bsi.ac.id, \\ hamdun.hsl@bsi.ac.id,muhamad.mag@bsi.ac.id
}

\begin{abstract}
Breast cancer is still a major health problem for women around the world, the population of Indonesia is 237.8 million in 2010 and detected by cancer patients is estimated at 1.02 million. The purpose of this study is to reconstruct the image of the MRI scan to clarify the object of cancer so that it can be more easily identified whether a person really has breast cancer or not, in this study using the morphological reconstruction method with the k-means algorithm to segment the image, the results obtained sensitivity of around $92.86 \%$, specificity of $78.57 \%$, and accuracy of $85.71 \%$.
\end{abstract}

Keywords - cancer, morphological reconstruction, k-means, image.

\begin{abstract}
Abstrak
Kanker payudara masih menjadi masalah kesehatan utama bagi wanita di seluruh dunia, Jumlah penduduk Indonesia 237,8 juta jiwa pada tahun 2010 dan terdeteksi penderita kanker diperkirakan 1,02 juta jiwa. Tujuan penelitian ini untuk merekonstruksi citra dari hasil scan MRI untuk memperjelas objek kanker sehingga dapat lebih mudah diidentifikasi apakah seseorang benar-benar terkena kanker payudara atau tidak, dalam penelitian ini menggunakan metode rekonstuksi morfologi dengan algoritma k-means untuk melakukan segmentasi citra, hasilnya didapatkan nilai sensitivitas sekitar $92,86 \%$, spesifisitas $78,57 \%$, dan akurasi $85,71 \%$.
\end{abstract}

Kata kunci - kanker, rekonstruksi morfologi, k-means, citra.

\section{1. Pendahuluan}

Pentingnya mendeteksi sel kanker sejak dini merupakan langkah awal dalam mengantisipasi berkembangnya sel kanker yang bersarang didalam tubuh manusia. Kanker payudara merupakan penyakit yang tergolong berbahaya bahkan dapat mengakibatkan kematian.

Kanker payudara masih menjadi masalah kesehatan utama bagi wanita di seluruh dunia. Bahkan, angka kejadian penyakit ini terus mengalami peningkatan dalam 10 tahun terakhir di berbagai belahan dunia. Data International Agency for Research on cancer (IARC) GLOBOCAN tahun 2012 mencatat bahwa 1,7 juta wanita terdiagnosis (insidensi) kanker payudara atau sekitar 11,9 persen dari seluruh insidensi kanker.
Sedangkan data WHO menunjukkan prevalensi kanker payudara di seluruh dunia mencapai 6,3 juta di akhir tahun 2012 yang tersebar di 140 negara.

Di Indonesia sendiri, kanker payudara menjadi penyakit yang menyerang beberapa perempuan dengan kasus kematian tertinggi sebesar angka 21,5 pada setiap 100.000 . Yang memperihatinkan, 70 persen pasien kanker payudara baru datang ke fasilitas kesehatan pada stadium lanjut.

Prevalensi penderita kanker di Indonesia mencapai 4,3 orang per 1000 penduduk. Dengan jumlah penduduk 237,8 juta jiwa pada tahun 2010, penderita kanker di Indonesiadiperkirakan 1,02 juta jiwa. Maka dari itu, agar dapat mengetahui sejauh mana penyebaran kanker pada payudara maka 
dilakukanlah rekonstruksi citra payudara hasil MRI dengan menggunakan segmentasi KMeans.

\section{Metodologi}

Pengolahan citra MRI kanker payudara dalam penelitian ini terdiri dari tahapan prepocessing yaitu dengan melakukan grayscaling yang selanjutnya dilakukan mask untuk menandai objek, tahapan kedua processing dengan melakukan rekonstruksi morfologi dan terakhir dilakukan segmentasi pada citra payudara.

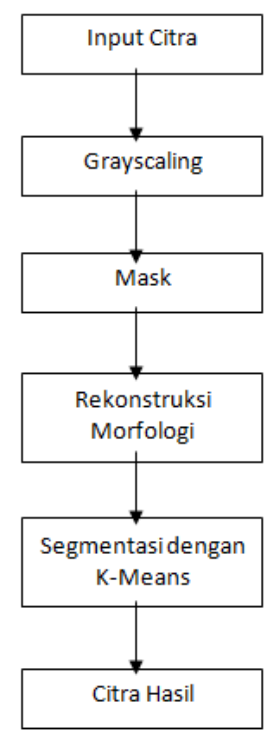

Sumber : (Nugroho, Ilcham, Jalil, \& Ardiyanto, 2017)

\section{Gambar. 1. Alur Proses Pengolahan Citra}

\section{Hasil dan Pembahasan}

Dalam penelitian ini objek yang digunakan berjumlah 28 citra payudara hasil scan menggunakan MRI (Magnetic Resonance Imaging). 28 citra tersebut terdiri dari 14 citra terdeteksi kanker dan 14 citra tidak terdeteksi kanker.

Sebelum dilakukan pengolahan citra untuk mendeteksi kanker payudara, pada 28 citra tersebut dilakukan tahapan pengolahan citra mulai dari preprocessing, processing dan clustering seperti terlihat pada gambar. 1 .

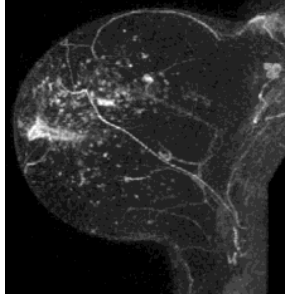

(a)

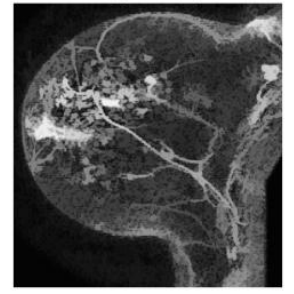

(c)

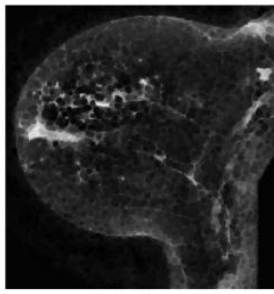

(b)

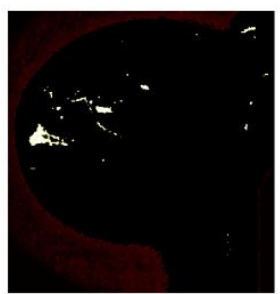

(d)
Sumber : radiology.com

Gambar. 1. Pengolahan rekonstruksi citra payudara

Pada gambar. 1 (a) merupakan citra asli hasil MRI, kemudian dilakukan preprocessing terhadap citra tersebut dengan melakukan grayscaling, kemudian disesusaikan kontrasnya untuk membuat citra mask (b), selanjutnya melakukan processing dengan membuat citra mask yang dapat mengidentifikasi objek dengan intensitas tinggi menggunakan rekonstruksi morfologi (c), selanjutnya dilakukan segmentasi citra dengan metode K-Means Clustering (d).

Dari hasil pengolahan citra tersebut akan dilakukan pemisahan objek (foreground) yang berwarna putih dan background yang berwarna hitam, semakin besar objek yang terlihat maka dapat diidentifikasikan bahwa objek tersebut merupakan kanker.

Kemudian dilakukan perhitungan untuk mengetahui nilai sensitivitas, spesifisitas dan akurasi berdasarkan data pada tabel 1 .

Keterangan $: \mathrm{TP}=$ True Positif, FN $=$ False Negatif, TN = True Negatif, FP = False Negatif 
JURNAL SWABUMI, Vol. 7 No.1 Maret 2019, pp. 67 71

ISSN: 2355-990X

\section{Tabel 1 \\ Hasil Uji Deteksi Citra Kanker Payudara}

Sumber : (Salih, Saracoglu, 2014)
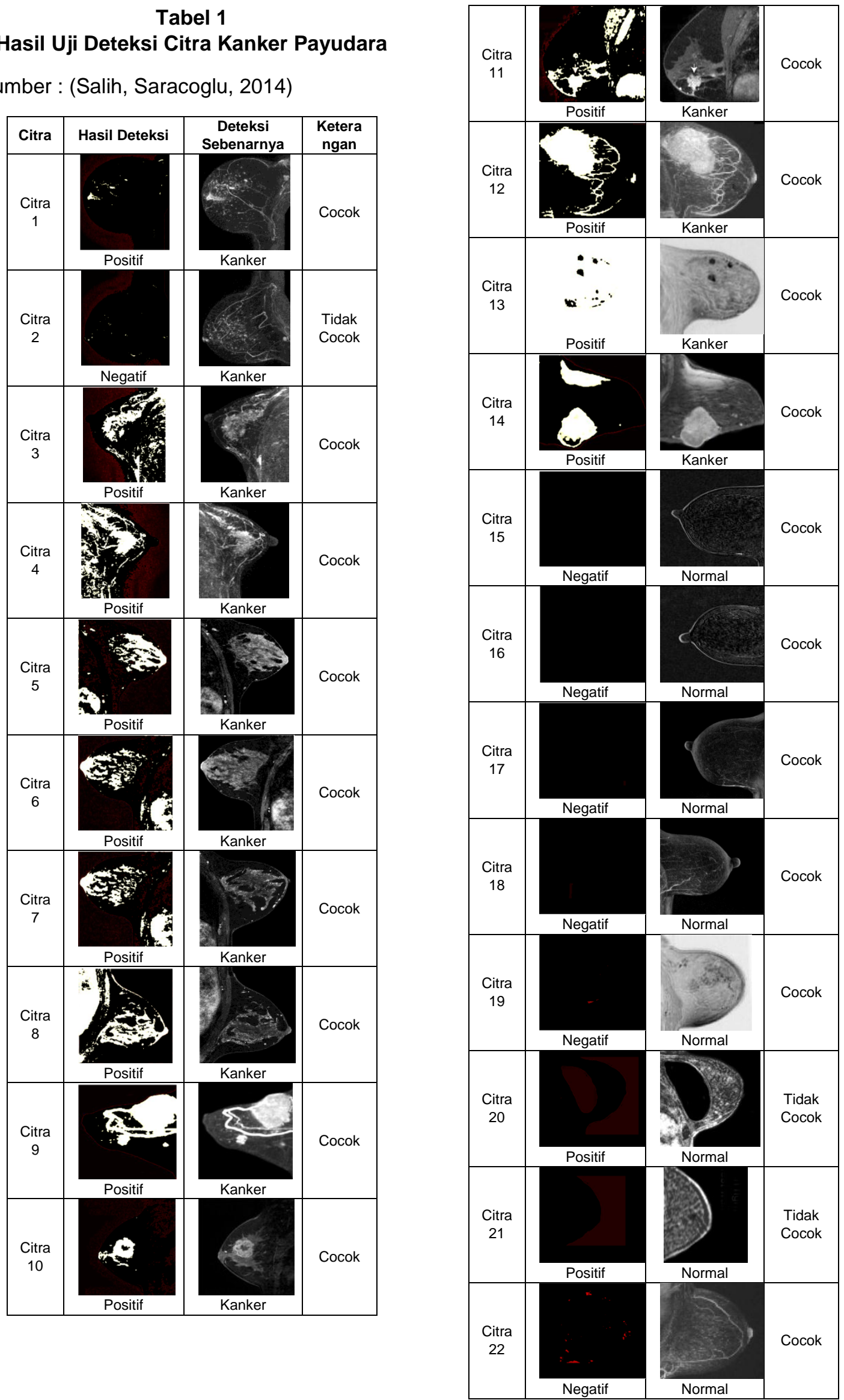


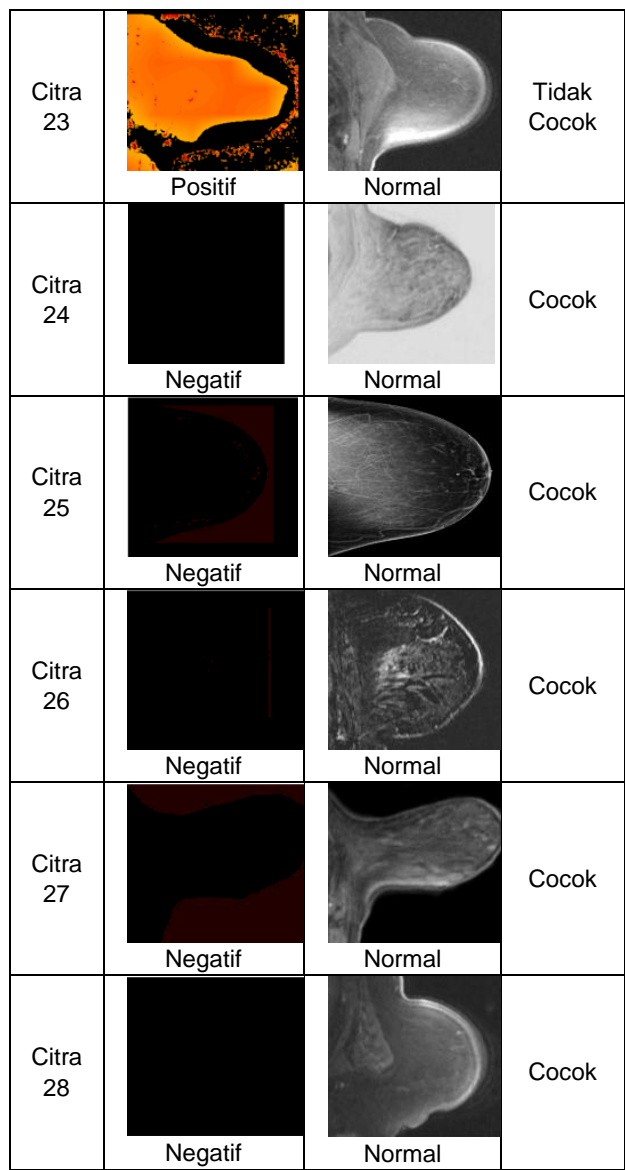

Pada tabel 1 dapat diketahui bahwa True Positif (TP) yaitu hasil deteksi positif dengan deteksi sebenarnya kanker sebanyak 13 , False Positif (FP) yaitu hasil deteksi positif dengan deteksi sebenarnya normal sebanyak 3 , True Negatif (TN) yaitu hasil deteksi negatif dengan deteksi sebenarnya normal sebanyak 11 dan False Negatif yaitu hasil deteksi negatif dengan deteksi sebenarnya kanker sebanyak 1.

$$
\begin{gathered}
\text { Sensitivitas }=\frac{\mathrm{TP}}{\mathrm{TP}+\mathrm{FN}} \times 100 \% \\
\text { Spesifisitas }=\frac{\mathrm{TN}}{\mathrm{TN}+\mathrm{FP}} \times 100 \% \\
\text { Akurasi }=\frac{\mathrm{TP}+\mathrm{TN}}{\mathrm{TP}+\mathrm{TN}+\mathrm{FP}+\mathrm{FN}} \times 100 \%
\end{gathered}
$$

Sesuai dengan persamaannya maka didapatkan nilai untuk sensitivitas 92,86\%, spesifisitas $78,57 \%$, dan akurasi $85,71 \%$.

\section{Kesimpulan}

Pengolahan citra MRI kanker payudara menggunakan metode rekonstruksi morfologi dengan algoritma K-Means terhadap 28 citra dilakukan dengan tahapan preprocessing, processing dan segmentasi dengan K-Means dari hasil pengujian terseut didapatkan nilai sensitivitas sekitar 92,86\%, spesifisitas $78,57 \%$, dan akurasi $85,71 \%$.

\section{Referensi}

Adi Hanung, I. A. (2016). Segmentation of Optic Disc on Retinal Fundus . International Conference on Science in Information Technology (ICSITech), 362.

Ashkan Tashk, M. S. (2015). Automatic Detection of Breast Cancer Mitotic Cells Based on the combination of Textural, Statistical and Innovative Mathematical Features. Accepted Manuscript, 1.

Fen Song, Z. X. (2013). Automatic Segmentation of Granules of the Solar Photosphere Using Morphological . International Conference on Intelligent Networks and Intelligent Systems, 300.

Luc vincent, M. I. (1993). Morphological Grayscale Reconstruction in Image Analysis : Applications and Efficient Algorithms. Transaction On Image Processing, 176.

Saheb Basha, S. P. (2009). AUTOMATIC DETECTION OF BREAST CANCER MASS IN MAMMOGRAMS USING MORPHOLOGICAL OPERATORS AND FUZZY C -MEANS CLUSTERING. Journal of Theoretical and Applied Information Technology, 704.

Salih Haydar, R. L. (2017). Automatic Detection and Segmentation of Breast . International Journal of Innovative Research in Science, 570.

Sharma Yamimi, Y. K. (2014). Brain Tumor Extraction From MRI Image Using Mathematical Morphological Reconstruction. 978-1-4799-69869/14/.

Wang Defeng, L. S. (2009). Automatic detection of breast cancers in mammograms using structured. Neurocomputing, 1. 
JURNAL SWABUMI, Vol. 7 No.1 Maret 2019, pp. 67 71

ISSN: 2355-990X

Wang Yang, X. J. (2015). Automated Identification of Sunspot Penumbral Grains Using Morphological. Conference Publishing Service, 13.

Yu Lan, L. D. (2014). Automated Sunspot Detection Using Morphological. Chinese Control Conference, 7168.

Zhangyuan GU, Y. S. (2015). Detection of infrared $\operatorname{dim}$ and small targets based on saliency and grayscale morphological reconstruction. Chinese Control Conference, 3811. 